\section{Abscisic Acid Accumulation in Leaves and Cultured Cells during Heat Acclimation in Grapes}

\author{
Mageed Abass and C.B. Rajashekar \\ Division of Horticulture, Kansas State University, Manhattan, KS 66506
}

Additional index words. Vitis spp., heat tolerance

Abstract. Heat tolerance and endogenous ABA levels in leaves and cultured grape cells (Vitis spp., cultivars Venus and Veeblanc) were evaluated during beat acclimation. Plants and cultured cells were acclimated at 38 and $36 \mathrm{C}$, respectively. Heat tolerance increased rapidly after exposing plants or cells to acclimation temperatures, reaching a maximum after 10 to 16 hours and 10 to 12 hours for leaves and cultured cells, respectively. Free and bound ABA levels increased sharply during the first hour of heat acclimation, before leaves and cultured cells reached their maximum beat tolerance. The increase in ABA during heat acclimation was 2- to 3-fold that of the nonacclimated control, and the time of the ABA accumulation peak in tissue roughly corresponded to the maximum heat tolerance in leaves and cultured cells. Heat tolerance was induced in cultured cells by exogenous ABA application. Heat tolerance increased significantly after 24 hours of ABA application at 7.6 or $9.5 \mu \mathrm{M}$. The results suggest that ABA may be a factor in high-temperature acclimation and beat-tolerance induction in grapes. Chemical name used: abscisic acid (ABA).

ABA is believed to play a role in plant tolerance to extreme environmental conditions (Salisbury and Marinos, 1985; Zeevaart and Creelman, 1988). Endogenous ABA accumulation in response to environmental stress has been shown in many plant species (Daie and Campbell, 1981; Eze et al., 1983; Skriver and Mundy, 1990; Zeevaart and Creelman, 1988). Many studies have demonstrated ABA accumulation during cold acclimation of plants and cold tolerance induction by exogenous ABA application (Bomman and Jansson, 1980; Chen and Gusta, 1983; Reaney et al., 1989). A similar ABA response has been noted with chilling temperatures and water stress (Hiron and Wright, 1973; Loveys and Kriedemann, 1973; Markhart, 1984). ABA may reduce chilling injury (Bomman and Jansson, 1980; Rikin and Richmond, 1976; Rikin et al., 1979) and the deleterious effects of water stress in plants (Mizrahi et al., 1974).

Although $\mathrm{ABA}$ accumulates in plants in

Received for publication 29 May 1992. Accepted for publication 24 Aug. 1992. Contribution no. 92601-J from the Kansas Agricultural Experiment Station. The cost of publishing this paper was defrayed in part by the payment of page charges. Under postal regulations, this paper must therefore be hereby marked advertisement solely to indicate this fact. response to high temperatures (Daie and Campbell, 1981; Daie et al., 1981), the role of $\mathrm{ABA}$ in heat acclimation, tolerance, and injury is not clear. Despite reports of increased ABA levels in plants exposed to high temperatures, little is known about the time-course ABA accumulation in plants during heat acclimation.

In the present study, we report ABA accumulation in leaves and suspension-cultured grape cells during heat acclimation and show the effects of exogenous ABA application on the heat tolerance of cultured grape cells.

Plant materials. Stem cuttings from 'Venus' and 'Veeblanc' grape hybrids were collected from the Ashland Horticultural Research Farm, Kansas. Thecuttings were rooted in a greenhouse under mist in pots containing a mixture of 1 peatmoss : 1 perlite $(\mathrm{v} / \mathrm{v})$. The rooted cuttings were repotted into larger pots and grown in the greenhouse at $25 \pm 3 \mathrm{C}$ and $80 \%$ relative humidity for 8 to 10 weeks.

Suspension-cultured cells. Callus cultures were initiated from 1- to 2-cm-long stem segments. Explants were surface-sterilized with aqueous $0.25 \%$ sodium hypochlorite for 20 min and rinsed three times in sterile distilled water. Explants were grown on Schenk and Hildebrandt ( $\mathrm{SH}$ ) solid medium (Schenk and Hildebrandt, 1972) containing $3.7 \mathrm{mg} \mathrm{1-}$ naphthaleneacetic acid (NAA) and $1.08 \mathrm{mg}$ kinetin/iter. Suspension-cultured cells were initiated from 7-week-old callus using $\mathrm{SH}$ liquid medium (same as above without agar). The cultures were maintained by subculturing $10 \mathrm{ml}$ of the suspension into $20 \mathrm{ml}$ of fresh medium in 125-ml Erlenmeyer flasks every 10 days. The cultures were grown at $25 \mathrm{C}$ on an orbital shaker at $90 \mathrm{rpm}$. All experiments consisted of three replications.

Plant acclimation. The optimum temperature and duration of heat acclimation were determined in a preliminary experiment. For heat acclimation, 2-month-old plants were transferred to growth chambers and kept at $38 \mathrm{C}$ for 3 days.

Moisture content of the medium was monitored and maintained near field capacity. Suspension cultures were kept at 36C for $24 \mathrm{~h}$. Leaf and cell samples were collected every 4 $\mathrm{h}$ during the first $24 \mathrm{~h}$ of heat acclimation and then every $12 \mathrm{~h}$ for the remaining period. Heat tolerance of cultured cells was determined by subjecting the samples to $42 \mathrm{C}$ for various lengths of time. Samples were then held for 12 $\mathrm{h}$ at room temperature before measuring conductivity using a conductance meter (YSI 32, Ohio). Conductivity was measured again after subjecting the samples to $80 \mathrm{C}$ for $30 \mathrm{~min}$ and then keeping them at room temperature for 12 h. The percent electrolyte leakage was plotted against the exposure time, and the transition midpoint was considered the lethal exposure time.

Endogenous ABA determination. Samples of fully expanded leaves and cultured cells were collected before and during acclimation at $0.5,1$, and $6 \mathrm{~h}$, and subsequently every $6 \mathrm{~h}$ for the first $24 \mathrm{~h}$, and then every $12 \mathrm{~h}$ for the

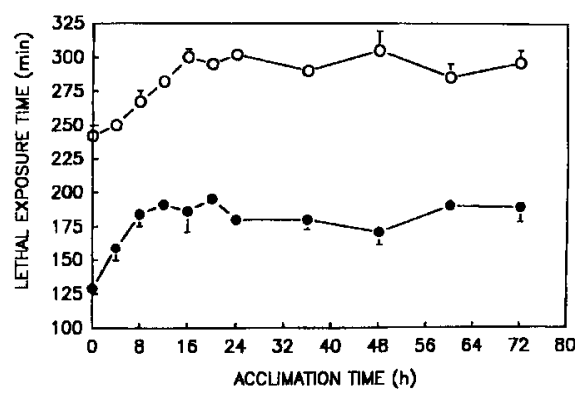

Fig. 1. Changes in heat tolerance in grape leaves during heat acclimation. Leaves of 'Venus' $(O)$ and 'Veeblanc' ( $)$ were subjected to $42 \mathrm{C}$, and lethal exposure time was determined based on the electrolyte leakage test. The plants were acclimated at $38 \mathrm{C}$. 
remaining period. Samples were dipped immediately in liquid nitrogen and then freezedried. The freeze-dried samples were ground to a fine powder using a Wiley mill. Procedures of Takeda and Crane (1980) were used for ABA extraction and purification. Free and bound $\mathrm{ABA}$ were quantified following the procedure of Durley et al. (1982). We used a dual-pump gradient high-performance liquid chromatograph (HPLC) (ISCO, Nebraska) equipped with a $250-\mathrm{mm} \times 4.6-\mathrm{mm}$ Econosil reverse-phase $\mathrm{Cl} 8$ column (Alltech Assoc., Illinois).

Exogenous ABA application and heat tolerance. Suspension cultures $(50 \mathrm{ml})$ were incubated with 3.8, 7.6, and 9.5 $\mu \mathrm{M}$ of (+)-ABA (Sigma, St. Louis) for $24 \mathrm{~h}$. The exposure time was based on the maximum response to $\mathrm{ABA}$ in preliminary experiments. Cells were centrifuged and washed three times with $0.3 \mathrm{M}$ mannitol before being suspended in $\approx 10 \mathrm{ml}$ of $0.3 \mathrm{M}$ mannitol. Heat tolerance of cultured cells was determined using the procedure described above.

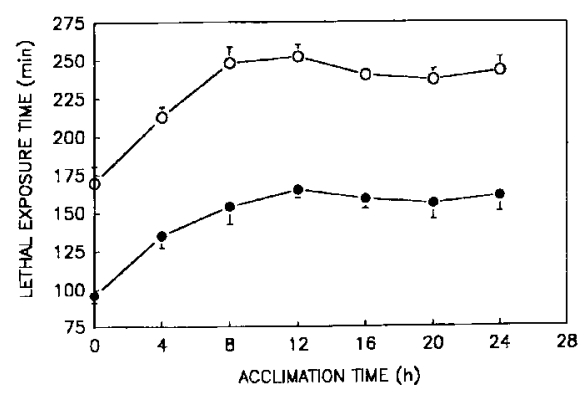

Fig. 2. Changes in heat tolerance in suspensioncultured cells of grapes during heat acclimation. The cultured cells of 'Venus' ( $O$ ) and 'Veeblanc' (- ) were subjected to $42 \mathrm{C}$, and lethal exposure time was determined based on the electrolyte leakage test. The cells were acclimated at 36C.
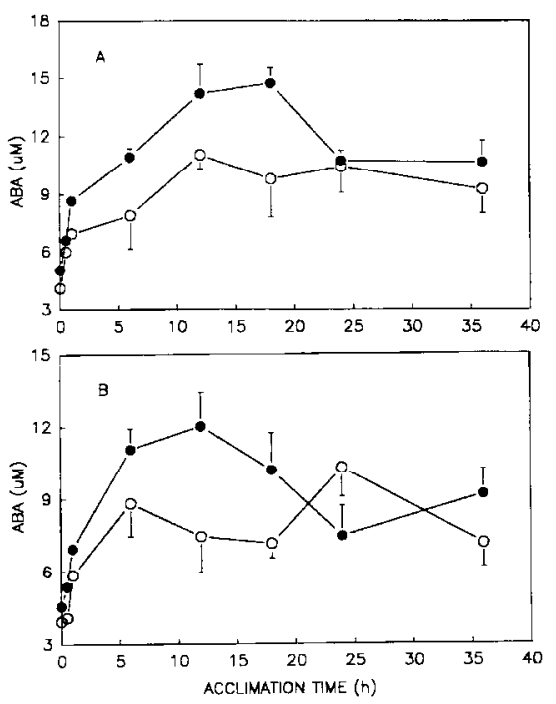

Fig. 3. Changes in free and bound endogenous $A B A$ levels in grape leaves during heat acclimation. 'Venus' (A) and 'Veeblanc' (B) plants were acclimated at 38C, and free ( $)$ and bound $(O)$ ABA levels in leaves were determined during acclimation.
Leaf heat tolerance increased and reached a maximum in 10 to $16 \mathrm{~h}$ and showed little change afterward (Fig. 1). 'Venus' was more heat tolerant than 'Veeblanc' before and during heat acclimation. The increase in lethal exposure time at $42 \mathrm{C}$ was 50 to $60 \mathrm{~min}$ in response to acclimation. The acclimation response of cultured cells was similar to that of leaves (Fig. 2). The cells reached a maximum heat tolerance in 10 to $12 \mathrm{~h}$ during acclimation. These results are consistent with those from previous studies on many plant species (Chen et al., 1982; Lester, 1985; Santarius and Muller, 1979).

Free and bound ABA levels were monitored in leaves during acclimation. A sharp increase in free $\mathrm{ABA}$ was observed immediately after subjecting the plants to acclimation (Fig. 3). The free ABA level in leaves increased $\approx 3$ - fold and reached a maximum between 6 to $18 \mathrm{~h}$ during acclimation. The initial peak of free ABA level was followed by a large decline; however, the free ABA levels were much higher in leaves during acclimation than in the nonacclimated control. Studies by Daie and Campbell (1981) showed that ABA accumulated in tomato (Lycopersicon esculentum Mill) and pea (Pisum sativum L.) (Daie et al., 1981) plants after exposure to 35 to $48 \mathrm{C}$ for $24 \mathrm{~h}$.

Changes in bound and free ABA levels of leaves were similar during acclimation (Fig. 3 ). Bound ABA levels peaked slightly sooner, and the initial peak for bound $\mathrm{ABA}$ was smaller than that for free ABA. Bound ABA levels were higher in acclimated leaves than in the nonacclimated control.

The changes in free and bound ABA in cultured cells were similar to those in leaves (Fig. 4); however, the rise in free and bound ABA levels during acclimation was observed sooner in cultured cells than in leaves. These
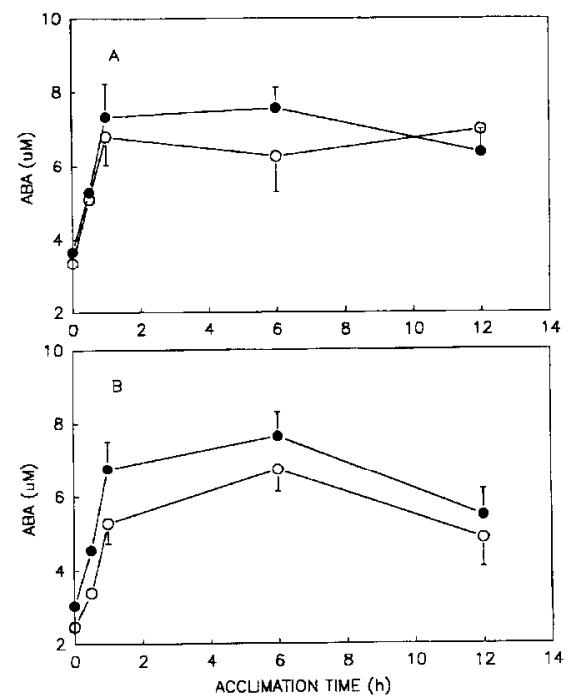

Fig. 4. Changes in free and bound endogenous $A B A$ levels in suspension-cultured cells of grapes during heat acclimation. The cultured cells of 'Venus' (A) and 'Veeblanc' (B) wereacclimated at 36C, and free ( ) and bound ( $O$ ) ABA levels were determined in cells during acclimation. results suggest that $\mathrm{ABA}$ accumulation in leaves and cultured grape cells was associated with high-temperature acclimation. Similar observations have been noted in many plant species exposed to temperature stress (Hiron and Wright, 1973; Rikin et al., 1976). A close association between ABA accumulation and peak cold tolerance was observed in potato (Solanum tuberosum L.) leaves (Chen et al., 1983). Although we observed rapid ABA accumulation in cultured cells during acclimation, the maximum levels of free and bound $\mathrm{ABA}$ in cultured cells were lower than those in leaves.

In leaves and cultured cells, there was a rapid increase of free and bound $\mathrm{ABA}$ in response to acclimation treatment. In leaves, levels of free and bound ABA increased $>50 \%$ over the control within $1 \mathrm{~h}$ of acclimation. In cultured cells, free and bound ABA levels rose by $>100 \%$ over the control during the first hour of acclimation. This increase accounts for $>74 \%$ of the free ABA accumulation in cells occurring during acclimation. The sharp increase in ABA levels occurred well before leaves and cultured cells reached the maximum heat tolerance during acclimation. Nonetheless, peak ABA accumulation during heat acclimation coincided with peak heat tolerance, as with cold tolerance. However, ABA's response in relation to cold tolerance was observed after a few days of acclimation at low temperature and corresponded to peak cold tolerance (Chen et al., 1983).

Heat tolerance increased significantly $(\mathrm{F}$ test, $P<0.05)$ within $24 \mathrm{~h}$ of ABA application at 7.6 or $9.5 \mu \mathrm{M}$ (Fig. 5). Cold tolerance has increased similarly in plants in response to exogenous ABA (Bomman and Jansson, 1980; Chen and Gusta, 1983; Rikin et al., 1979). ABA treatment has been shown to substitute for acclimation at low temperatures (Chen and
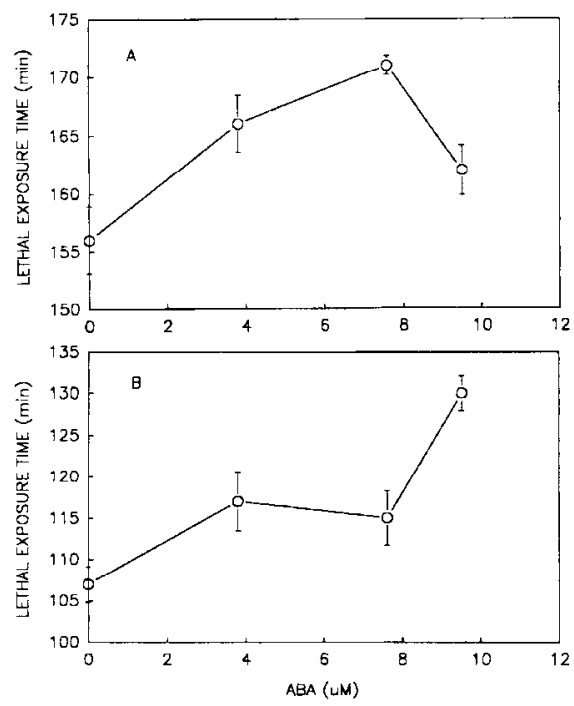

Fig. 5. Heat tolerance in cultured grape cells in response to exogenous ABA application. The cultured cells of 'Venus' (A) and 'Veeblanc' (B) were treated with $\mathrm{ABA}$ for $24 \mathrm{~h}$, and lethal exposure time was determined based on the electrolyte leakage test. 
Gusta, 1983; Chen et al., 1983). In many cases, the increase in cold tolerance from ABA application was greater than that from acclimation at low temperatures (Chen and Gusta, 1983). However, our results show that the increase in heat tolerance from exogenous ABA application was smaller due to acclimation at 36C. The increase in lethal exposure time for cultured cells from exogenous ABA applications ranged from 15 to $23 \mathrm{~min}$. This diminished response to exogenous $\mathrm{ABA}$ application compared to acclimation at $36 \mathrm{C}$ suggests that $\mathrm{ABA}$ accumulation in cells is only one of many factors associated with the process of heat acclimation in grapes.

\section{Literature Cited}

Bomman, C.H. and E. Jansson. 1980. Nicotiana tabacum callus studies. X. ABA increases resistance to cold damage. Physiol. Plant. 48:491-493.

Chen, H.H. and L.V. Gusta. 1983. Abscisic acidinduced freezing resistance in cultured plant cells. Plant Physiol. 73:71-75.

Chen, H.H., P.H. Li, and M.L. Brenner. 1983. Involvement of abscisic acid in potato cold acclimation. Plant Physiol. 71:362-365.

Chen, H.H., Z.Y. Shen, and P.H. Li. 1982. Adaptability of crop plants to high temperature stress. Crop Sci. 22:719-725.

Daie, J. and W.F. Campbell. 1981. Response of tomato plants to stressful temperatures. Increase in abscisic acid concentrations. Plant Physiol. 67:26-29.

Daie, J., W.F. Campbell, and S.D. Seeley. 1981. Temperature-stress-induced production of abscisic acid and dihydrophaseic acid in warm and cool-season crops. J. Amer. Soc. Hort. Sci. 106(1):11-13.

Durley, R.C., T. Kannangara, and G.M. Simpson. 1982. Leaf analysis for abscisic, phaseic and 3indolylacetic acids by high-performance liquid chromatography. J. Chromatography 236: 181.

Eze, J.M., E.B. Dumbroff, and J.E. Thompson. 1983. Effects of temperature and moisture stress on the accumulation of abscisic acid in bean. Physiol. Plant. 58:179-183.

Hiron, R.W. and S.T. Wright. 1973. The role of endogenous abscisic acid in the response of plants to stress. J. Expt. Bot. 24(81):769-781.

Lester, G.E. 1985. Leaf cell membrane thermostabilities of Cucumis melo. J. Amer. Soc. Hort. Sci. 110(4):506-509.

Loveys, B.R. and P.E. Kriedemann. 1973. Rapid changes in abscisic acid-like inhibitors following alterations in vine leaf water potential. Physiol. Plant. 28:476-479.

Markhart, A.H. 1984. Amelioration of chillinginduced water stress by abscisic acid-induced changes in root hydraulic conductance. Plant Physiol. 74:81-83.

Mizrahi, Y.S., S.G. Scherings, S. Arad, and A.E. Richmond. 1974. Aspects of the effect of ABA on the water status of barley and wheat seedlings. Physiol. Plant. 31:44-50.

Reaney, M.J.T., M. Ishikawa, A.J. Robertson, and
L.V. Gusta. 1989. The induction of cold acclimation: The role of abscisic acid, p. 3-25. In: P.H. Li (ed.). Low temperature stress physiology in crops. CRC, Boca Raton, Fla.

Rikin, A., D. Atsmon, and C. Gitler. 1979. Chilling injury in cotton (Gossypium hirsutum L.): Prevention by abscisic acid. Plant Cell Physiol. 20(8):1537-1546.

Rikin, A., A. Blumenfeld, and A.E. Richmond. 1976. Chilling resistance as affected by stressing environments and abscisic acid. Bot. Gaz. 137(4):307-312.

Rikin, A. and A.E. Richmond. 1976. Amelioration of chilling injuries in cucumber seedlings by abscisic acid. Physiol. Plant. 38:95-97.

Salisbury, F.B. and N.G. Marinos. 1985. The ecological role of plant growth substances. Encyclopedia Plant Physiol. 11:707-766.

Santarius, K.A. and M. Muller. 1979. Investigations on heat resistance of spinach leaves. Planta 146:529-538.

Schenk, R.U. and A.C. Hildebrandt. 1972. Medium and techniques for induction and growth of monocotyledonus and dicotyledonous plant cell cultures. Can. J. Bot. 50:199-204.

Skriver, K. and J. Mundy. 1990. Gene expression in response to abscisic acid and osmotic stress. Plant Cell 2:503-512.

Takeda, F. and J.C. Crane. 1980. Abscisic acid in pistachio as related to inflorescence bud abscission. J. Amer. Soc. Hort. Sci. 105:573-576.

Zeevaart, J.A. and R.A. Creelman. 1988. Metabolism and physiology of abscisic acid. Annu. Rev. Plant Physiol. 39:439-473. 